Portland State University

PDXScholar

Environmental Science and Management

Faculty Publications and Presentations

7-12-2011

\title{
Carbon Sequestration in the New Jersey Pine Barrens Under Different Scenarios of Fire Management
}

\author{
Robert M. Scheller \\ Portland State University, rmschell@pdx.edu \\ Steve Van Tuyl \\ USDA Forest Service \\ Kenneth L. Clark \\ USDA Forest Service \\ John Hom \\ USDA Forest Service \\ Inga La Puma \\ Rutgers University
}

Follow this and additional works at: https://pdxscholar.library.pdx.edu/esm_fac

Part of the Environmental Sciences Commons

Let us know how access to this document benefits you.

\section{Citation Details}

Scheller, R., Van Tuyl, S., Clark, K., Hom, J., \& La Puma, I. (2011). Carbon Sequestration in the New Jersey Pine Barrens Under Different Scenarios of Fire Management. Ecosystems, 14(6), 987-1004. doi:10.1007/ s10021-011-9462-6

This Article is brought to you for free and open access. It has been accepted for inclusion in Environmental Science and Management Faculty Publications and Presentations by an authorized administrator of PDXScholar. Please contact us if we can make this document more accessible: pdxscholar@pdx.edu. 


\title{
Carbon Sequestration in the New Jersey Pine Barrens Under Different Scenarios of Fire Management
}

\author{
Robert M. Scheller, ${ }^{1 *}$ Steve Van Tuyl, ${ }^{2,5}$ Kenneth L. Clark, ${ }^{3}$ John Hom, ${ }^{2}$ \\ and Inga La Puma ${ }^{4}$
}

\begin{abstract}
${ }^{1}$ Department of Environmental Sciences and Management, Portland State University, P.O. Box 751, Portland, Oregon 97207, USA; ${ }^{2}$ USDA Forest Service, 11 Campus Blvd, Newtown Square, Pennsylvania 19073, USA; ${ }^{3}$ Silas Little Experimental Forest, USDA Forest Service, 501 Four Mile Road, New Lisbon, New Jersey 08064, USA; ${ }^{4}$ Center for Remote Sensing and Spatial Analysis, Rutgers
\end{abstract} University, New Brunswick, New Jersey 08873, USA; ${ }^{5}$ Pittsburgh, Pennsylvania, USA

\begin{abstract}
The New Jersey Pine Barrens (NJPB) is the largest forested area along the northeastern coast of the United States. The NJPB are dominated by pine (Pinus spp.) and oak (Quercus spp.) stands that are fragmented and subject to frequent disturbance and forest management. Over long time periods ( $>50$ years), the balance between oak and pine dominance is determined by fire frequency. As a consequence, the ability of the NJPB to sequester carbon may be contingent upon management activities as well as patterns of historic land use. We simulated 100 years of carbon change using three scenarios: (1) contemporary management as reflected in the recent (1991-2006) fire records, (2) an increase in the fire ignitions within the wildland
\end{abstract}

Received 13 December 2010; accepted 18 May 2011; published online 12 July 2011

Author Contributions: Scheller: Primary author, conducted all simulations. Van Tuyl: Gathered and summarized parameterization data. Created fuel types and conducted cross-tabulation with FBFM fuel types. Created all maps. Clark: Provided flux tower data and guided the analysis of net ecosystem exchange. Hom: Coordinated data acquisition and cowrote the Discussion. La Puma: Provided empirical fire data and assisted with fire calibration.

*Corresponding author; e-mail: rmschell@pdx.edu urban interface areas of the NJPB reflecting increased prescribed fires, and (3) a longer response time to wildfires, reflecting a more liberal burning policy by the New Jersey Forest Fire Service. We used the LANDIS-II model coupled with CENTURY and the Dynamic Fire and Dynamic Biomass Fuels extensions to estimate forest carbon sequestration based on these three scenarios. Calibration and validation via comparison to monthly flux tower data indicated that the model reasonably captured the timing and magnitude of net ecosystem exchange in the absence of Gypsy moth defoliation $\left(r^{2}=0.89\right)$. Under all scenarios, our simulations suggest that forests of the NJPB will continue to accumulate carbon over the next 100 years under current climatic conditions. Although aboveground net primary productivity, live carbon, and detrital carbon were roughly constant or increased only modestly, soil organic carbon continued to increase through time for all forest types except the highly xeric pine plains. Our simulated changes in management reflected only minor alterations to the fire regime and thus management may have only minor effects on total forest carbon budgets in the immediate future particularly when compared to recovery from historic disturbance patterns.

Key words: CENTURY; net ecosystem exchange; New Jersey Pine Barrens; fire emissions; fire management; soil organic carbon; eddy flux tower; LANDIS-II. 


\section{INTRODUCTION}

New Jersey passed the Global Warming Response Act in 2007, and since then the state has been developing a plan to reduce greenhouse gas emissions by maintaining or increasing the amount of carbon sequestered in terrestrial ecosystems, primarily forests. Accounting for natural disturbances which result in greenhouse gas emissions is a necessary component of any plan to manage terrestrial carbon sequestration in forests. However, accurate determination of the effects of such disturbances on carbon sequestration is difficult, given the complexity of interactions between natural disturbances (for example, wildfires, insect defoliation, wind damage) and climatic driving variables. Previous research has highlighted how standreplacing disturbances can have much larger effects on long-term carbon storage and fluxes than interannual variability in climate (for example, Thornton and others 2002; Amiro and others 2010). For example, Campbell and others (2007) showed that the emissions from large wildfires can significantly affect regional carbon balance in a given year. Transient, less-severe disturbances can also have substantial effects on the carbon dynamics of forest stands (Goward and others 2008; Lindroth and others 2009). Clark and others (2010b) found that Gypsy moth (Lymantria dispar L.) defoliation of approximately $20 \%$ of upland forest stands in southern New Jersey resulted in a $41 \%$ reduction in annual net ecosystem exchange of $\mathrm{CO}_{2}\left(\mathrm{NEE}_{\mathrm{Yr}}\right)$ at the landscape scale, with a $55 \%$ reduction in $\mathrm{NEE}_{\mathrm{yr}}$ estimated if only oak-dominated stands were considered.

The New Jersey Pine Barrens (NJPB) in southern New Jersey is comprised of upland pine, pine-oak, and oak forest interspersed with wetlands dominated by hardwoods and conifers (Skowronski and others 2007; Scheller and others 2008). Pre-colonial vegetation in other Atlantic Coastal Plain Pine Barrens systems were more oak-dominated (Kurczewski and Boyle 2000; Cogbill and others 2002 ), suggesting longer ( $>50$ years) fire rotation periods in these systems (Scheller and others 2008). During the post-colonial period, the NJPB experienced large wildfires due to logging and slash buildup and an increase in human-caused ignitions (Wacker 1979). The incidence of large wildfires has been reduced since the 1940s due to fire suppression with better equipment (Forman and Boerner 1981). From 1991 to 2006, the NJPB experienced an average of 934 wildfires per year (I. La Puma, unpublished data). Although fires in the NJPB tend to be small due to aggressive fire suppression activities, meteorological and fuel conditions occasionally result in fires greater than $4000 \mathrm{ha}$, and sometimes much larger (Forman and Boerner 1981).

Given the extensive amount of wildland urban interface (WUI) surrounding the nearly continuous forests in the Pinelands National Reserve, major wildfires continue to be a major point of concern in the state. For instance, a 6880 ha wildfire in May of 2007 resulted in the evacuation of about 2000 people, closure of major transportation corridors, and destroyed or damaged more than 60 structures. Fuel treatments have been suggested as a way to simultaneously lower fire risk and increase carbon storage in forests by releasing the growth potential of remaining trees and lowering the risk of catastrophic wildfire which releases large amounts of carbon to the atmosphere (Campbell and others 2007). Recent studies, however, have cast doubt on the potential for fuel reduction treatments to accelerate carbon storage in forests. For example, Mitchell and others (2009) showed that although fuel reduction treatments reduced fire severity, the carbon removed during fuel treatments exceeded those that might have occurred in a wildfire. However, Hurteau and North (2009) demonstrated a reduction in fire severity and carbon emissions in areas that were thinned prior to a wildfire.

For a prior modeling study of the NJPB (Scheller and others 2008), we constructed model scenarios that recreated the pre-colonial contiguous landscape with an estimated pre-colonial fire regime and scenarios of the contemporary landscape with current and potential fire management. Our simulations indicated that the contemporary landscape has shifted from a pine-dominated to an oakdominated state relative to the pre-colonial landscape. However, within areas currently managed with prescribed burning, a doubling of the mean annual area burned potentially caused a gradual reversion to pre-colonial conditions, although oaks will continue to retain a higher dominance than during the pre-colonial period (Scheller and others 2008).

The objective of this study was to estimate the current trajectory of total carbon sequestration-including forest soil carbon-based on current management in the NJPB. We also simulated the effects of two potential fuels management scenarios. First, we simulated the effects of an increase in the use of prescribed fire in extensive WUI areas of the NJPB. Second, we simulated a longer response time to fires, as an indicator of either a more liberal "wildland fire use" policy or a reduction in 
staffing within the state and federal wildland fire agencies. The study described herein is the first stage of a larger project that will also examine the effects of climate change and insect defoliation on carbon cycling in the NJPB.

\section{Methods}

\section{Study Area}

The NJPB encompass pine, oak and wetland forests covering much of southern New Jersey (Figure 1). The climate is cool temperate, with mean monthly temperatures of 0.3 and $23.8^{\circ} \mathrm{C}$ in January and June, respectively (1930-2004; NJ State Climatologist). Mean annual precipitation is $1123 \pm$ $182 \mathrm{~mm}$. The terrain consists of plains, low-angle slopes and wetlands, with a maximum elevation of $62.5 \mathrm{~m}$. Soils are derived from the Cohansey and Kirkwood Formations (Lakewood and Sassafras soil series), and are coarse-textured, sandy, acidic, and have low cation exchange capacity and nutrient status (Rhodehamel 1979; Tedrow 1986). Despite the widespread occurrence of sandy, well-drained, nutrient-poor soils, upland forests are moderately productive and fuels can accumulate rapidly (Pan and others 2006; Wright and others 2007; Clark and others 2009a).

Upland forests comprise $62 \%$ of forested lands of the NJPB, and are dominated by pitch pine (Pinus rigida Mill.) shortleaf pine (P. echinata Mill.), and numerous oaks (Quercus spp.) (Lathrop and Kaplan 2004). The uplands are often divided into three major communities: oak-dominated forests with scattered pines (Oak-pine), pine-dominated forests with oaks in the overstory (Pine-oak), and pitch pine-dominated forests with scrub oaks and shrubs in the understory (Pine-scrub oak; (McCormick and Jones 1973; Lathrop and Kaplan 2004). In addition, a number of areas are dominated by dwarf or pygmy pine-oak barrens characterized by pitch pine and various oaks of a diminutive stature. All upland forests have moderate to dense shrub cover in the understory, primarily Vaccinium spp., Galussacia spp., Kalmia spp., and Quercus spp. Sedges, mosses, and lichens are also present. Many of the dominant species are highly adapted to fire and readily resprout (Boerner 1981). Interlaced through the area are numerous rivers and streams; associated lowland forests are dominated by Atlantic white cedar (Chamaecyparis thyoides), red maple (Acer rubrum), swamp tupelo (Nyssa sylvatica), pitch pine, shortleaf pine, and mesic adapted oaks (mostly Q. alba L.).

\section{Model Description}

We evaluated changes in carbon and net ecosystem exchange (NEE) of carbon dioxide using the LANDIS-II forest succession and disturbance model (Scheller and others 2007, 2010) (Figure 2). LANDIS-II represents the landscape as a grid of interconnected cells, whereupon succession occurs; disturbances typically span many cells and are dependent upon the spatial context and configu-
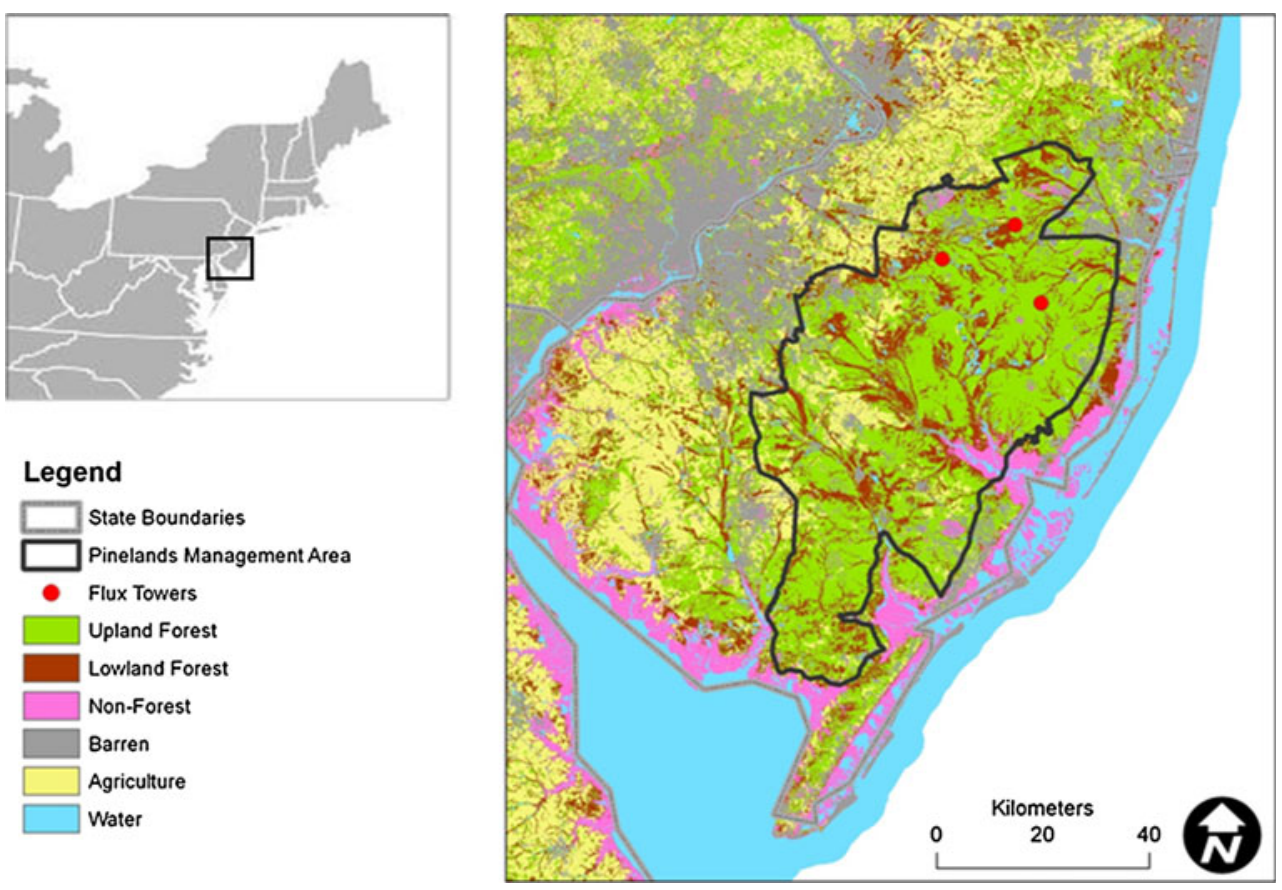

Figure 1. Study area showing general land cover classes and the location of the three eddy flux towers. 


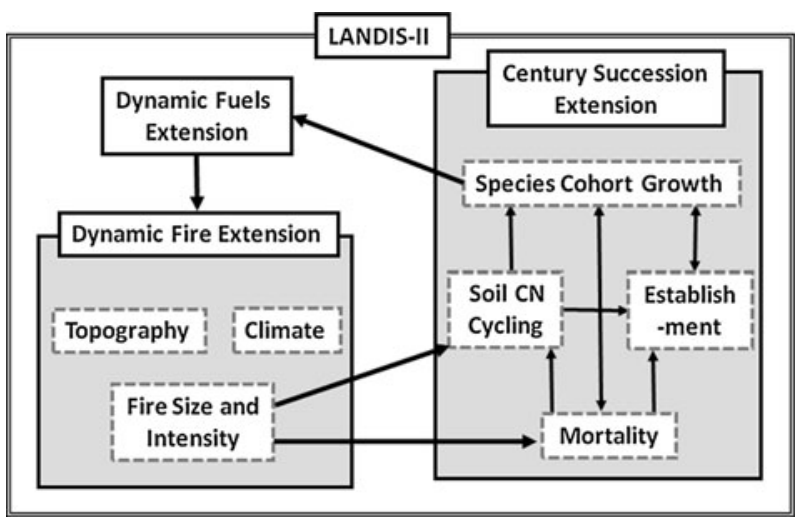

Figure 2. Conceptual diagram of LANDIS-II with the three principle extensions used in simulations of the NJ Pine Barrens. All components reside within the larger LANDIS-II forest modeling framework. Individual processes within extensions are indicated by dashed lines.

ration of the landscape. LANDIS-II requires species life history traits for each tree species (Table 1; data from Scheller and others 2008 and this study). Trees and shrubs are binned into cohorts that are defined by species and age.

LANDIS-II is a flexible modeling framework that allows a variety of alternative representations of succession and disturbance to be deployed. We used the Century succession extension (Scheller and others 2011) to simulate soil respiration and the establishment, growth, and mortality of species-age cohorts (Figure 2). The Century succession extension to LANDIS-II is derived principally from the CENTURY soil model (Parton and others 1983, 1993; Schimel and others 1994; Throop and others 2004). Within CENTURY, soils are divided into fast, slow, and passive soil organic matter (SOM) pools. Total soil respiration is dependent upon climate, edaphic properties (for example, percent sand and clay, field capacity, wilting point), and the structural and chemical properties of litter inputs (for example, percent lignin and $\mathrm{C}: \mathrm{N}$ ratios of leaves, aboveground wood, fine roots, and coarse roots). Growth rates for tree species cohorts generally follow the CENTURY logic and are determined by temperature, available water, available nitrogen; an overall maximum capacity for aboveground biomass helps regulate competition among species and cohorts. The Century succession extension operates at a monthly time step although simulated disturbances operate at an annual time step. Due to the temporal discontinuity, disturbances were simulated to occur at the end of July (Scheller and others 2011). Because the Century succession extension calculates aboveground and below ground net primary production (ANPP and BNPP, respectively) and heterotrophic respiration, NEE can be estimated at a monthly time step. Within the Century succession extension, the probability of establishment is fully incorporated such that changes in climate are reflected in both growth rates and reproduction.

In conjunction with the Century succession extension, we also used the Dynamic Fire and Dynamic Biomass Fuels extensions (Sturtevant and others 2009) (Figure 2). The Dynamic Fire extension combines information about each fuel type (including typical ignition rates, crown to base height, and spread rate under variable weather conditions) with climate and topographic information to determine the probability of ignition and spread (Sturtevant and others 2009). The Dynamic Biomass Fuels extension assigns a fuel type to each forested cell within the landscape dependent upon the biomass of the extant tree species (details below).

\section{Model Parameterization and Calibration}

We stratified the landscape into seven land types (or 'ecoregions') within which climate and soils were assumed to be homogeneous (Figure 3). The land types were developed by separating the study area into upland and lowland sites based on a current land-cover map (Lathrop and Kaplan 2004) and then further clustering these broad landforms into three classes of soil water holding capacity based on the NRCS SSURGO dataset (NRCS 2011) resulting in six land types. We then added an additional land type representing the dwarf pine barrens areas, based on forest mapping described in Givnish (1981). Non-forested areas (including urban, agriculture, and non-forested uplands and wetlands) were inactive in all simulations although they generate landscape fragmentation and fire breaks (Scheller and others 2008). Climate data were not used in the designation of land types given the flat nature of the topography and the lack of substantial temperature and precipitation gradients in the study area.

We selected 14 dominant tree species to represent the forests of the study area. Using forest inventory data (Hansen and others 1992; Service 2007), we identified the 10 tree species that represented over $90 \%$ of the trees in the inventory data within our study area. In addition, four species were selected that represent important components of succession dynamics or were a critical part of the fuel bed in some forest types (Scheller and others 2008; Table 1). 


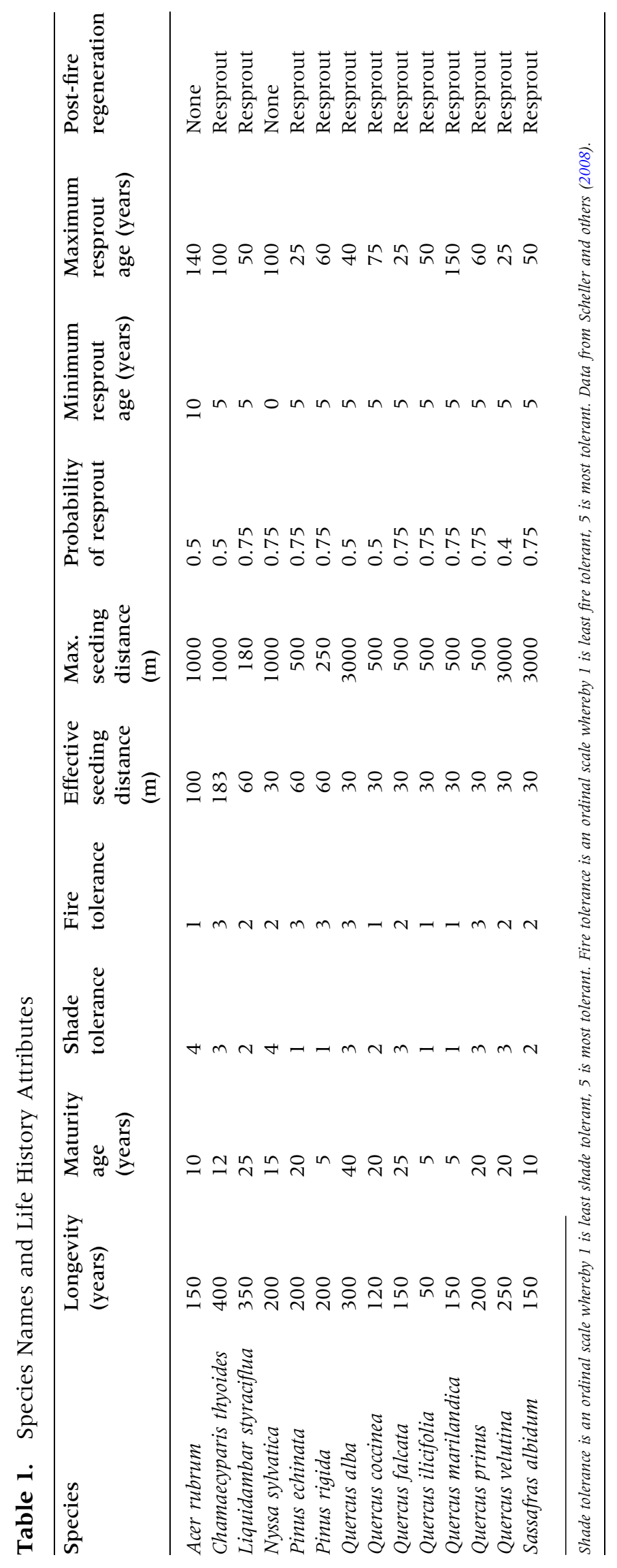




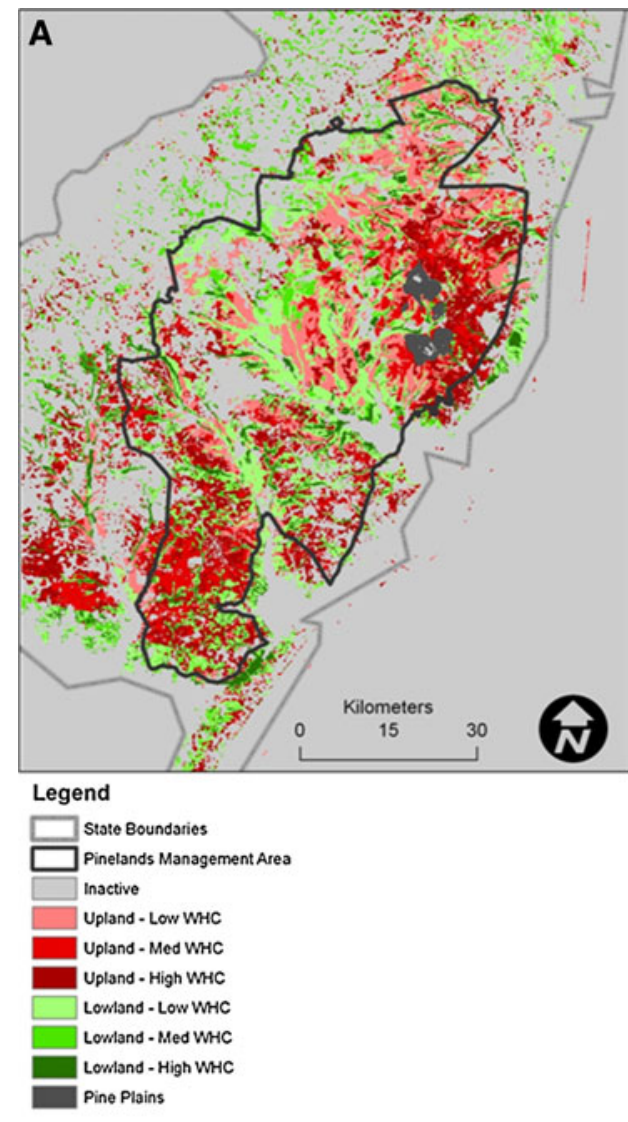

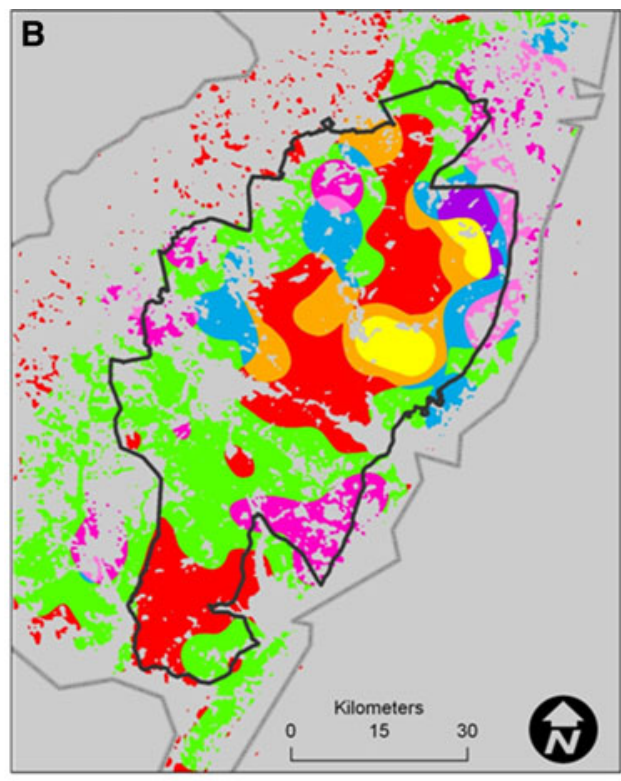

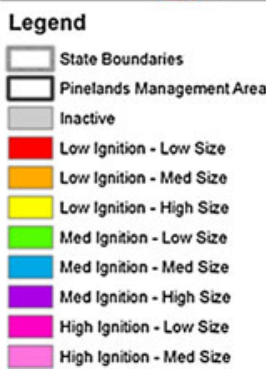

Figure 3. Delineation of land types $(\mathbf{A})$ and fire regions $(\mathbf{B})$. Land types were derived from a land cover map (Lathrop and Kaplan 2004) and three classes of soil water holding capacity based on the NRCS SSURGO

dataset. Fire regions were generated from classified maps of ignition density and fire size density interpolations using ignition point locations and a fire size attribute associated with ignition points.
The initial communities map and database for the simulations were derived from the US Forest Service Forest Inventory and Analysis (FIA; http:// fia.fs.fed.us/) data and a $30 \mathrm{~m}$ pixel size land-cover map developed for the state of New Jersey (Lathrop and Kaplan 2004). For each FIA plot, we calculated the age of each tree based on DBH to age relationships developed for the entire dataset. We then generated age cohorts to represent the initial communities on the landscape by identifying the unique species-age combinations for each FIA plot. Next, we transformed the land-cover map to generate a map with unique polygons, each associated with a forest type. Then, for each polygon, we randomly assigned the attributes of an FIA plot from the pool of plots associated with that forest type, resulting in a dataset of initial conditions with a single set of age cohorts for each polygon for the initial community map.

\section{Century Succession Extension}

Successional dynamics and individual tree species responses to disturbance were previously evaluated for the NJPB (Scheller and others 2008). For the current study and objectives, we focused on the calibration and validation of aboveground net primary productivity (ANPP) and NEE, two ecosystem carbon fluxes that are critical to understanding carbon cycling across the landscape over time. Within the NJPB, three flux towers have been recording NEE since 2005 (Clark and others 2010b; data available at http://public.ornl.gov/ameriflux/; Figure 1). We calibrated modeled monthly NEE against observed NEE at an Oak-pine stand at the Silas Little Experimental Forest, and then evaluated model predictions by comparison to flux data collected at the Pine-oak and Pine-scrub oak stands. Each flux tower comparison was conducted by simulating a single cell in the absence of disturbance using tree species data collected around each flux tower to represent initial conditions. Monthly meteorological data collected at each flux tower were input into the model for the calibrations. Soils data collected at each flux tower (Table 2) were input for each calibration simulation. Calibration required adjustment of the species temperature parameters to represent the phenology of ANPP (see Scheller and others 2011). Calibration also required adjustment of the relationship between $\mathrm{N}$ 
Table 2. Soil Parameters for the Three Flux Tower Sites in the New Jersey Pine Barrens

\begin{tabular}{lllll}
\hline Flux tower & $\begin{array}{l}\text { Fraction } \\
\text { clay }\end{array}$ & $\begin{array}{l}\text { Fraction } \\
\text { sand }\end{array}$ & $\begin{array}{l}\text { Field capacity } \\
\text { (fraction) }\end{array}$ & $\begin{array}{l}\text { Wilting } \\
\text { point (fraction) }\end{array}$ \\
\hline Cedar Bridge & 0.067 & 0.818 & 0.129 & 0.045 \\
Fort Dix & 0.035 & 0.917 & 0.103 & 0.027 \\
Silas Little & 0.055 & 0.865 & 0.108 & 0.04 \\
Forested Wetlands & 0.066 & 0.837 & 0.22 & 0.094 \\
\hline
\end{tabular}

deposition and precipitation. We lacked reliable measurements of wet and dry $\mathrm{N}$ deposition across the study area, therefore, we compared our calibrated estimates to data from nearby coastal areas in NJ (Gao and others 2007).

For each land type, the Century extension requires initial estimates of soil carbon and nitrogen. These estimates, along with the suite of edaphic parameters required by the extension were derived from the USDA NRCS soil survey data for the state of New Jersey (NRCS 2011; Table 3). For the forested wetlands (ca. 38\% of the study areas), base and storm flow fractions were reduced by half to represent the poorer drainage typical of wetland areas.

\section{Dynamic Fire System Extension}

We used a moderate resolution map of the fire behavior fuel models (FBFM) developed by Scott and Burgan (2005) as a guide for assigning spread rate parameters for the Dynamic Fire System (DFS) extension. Using equations provided in Scott and Burgan (2005), we calculated rate of spread (ROS) for the eight FBFMs (out of their original 40) that represented greater than $2 \%$ of that landscape. We calculated ROS for each FBFM under the range of wind speeds and the most frequent fine fuel moisture ( 1 -h fuels) values encountered during the fire season in the NJPB based on a combined 15 years of fuel moisture data collected at four separate sites. By comparing distributions of fine fuel moisture with the values presented in Scott and Burgan (2005), we selected two of the four moisture conditions for matching the eight FBFM models with the DFS models ( $1-\mathrm{h}$ fuel moisture content 9 and $12 \%$ ). In all cases, live fuel moisture was set at 120 and $90 \%$ for herbaceous and woody fuels, respectively, based on preliminary fire season field measurements.

For each FBFM, we calibrated the DFS equations to achieve the lowest residual standard error of a regression of each FBFM ROS against the corresponding DFS fuel type ROS. For calibration, we altered the three parameters $(a, b$, and $c)$ that define the shape of the ROS curve and $q$, which defines the effect of Buildup Index on ROS (Sturtevant and others 2009). Though the parameter values were allowed to vary without restriction, we required the FBFM on DFS regression model to have a slope between 0.95 and 1.05 (ensuring equivalence of ROS values) and an intercept of $0 \pm 15 \%$ of the mean FBFM ROS value (ensuring a relatively small offset in ROS values).

Fire regions were developed using an extensive database of fire occurrence and fire sizes going back to 1929 with complete records from 1991 to 2006, provided by the NJ Forest Fire Service (I. La Puma, unpublished data). Ignition points were interpolated via a kernel density method and classified via unsupervised classification into low, medium and high ignition density areas. In addition, a kernel density interpolation was performed on the fire size associated with each ignition point which was also classified into low, medium, and high fire size areas. Subsequently, these three class layers were combined to form eight fire regions so that fire regions would represent both ignition density and fire size (Figure 3B). The high ignition, high fire size category was dropped for lack of ignition data and those data were subsumed into the medium ignition, high fire region. Because fire regions represent both ignition density and fire size density layers, ignition point counts extracted from each fire region and used for modeling were not indicative of ignition densities alone (Table 5). The fire occurrence database was also used to generate parameters related to the seasonality of fires in each region.

Fire weather inputs (wind speed, wind direction, fire weather index, and build-up index; see Sturtevant and others 2009) to the DFS were created using standard equations from the Canadian Forest Fire Weather Index System (Van Wagner 1987). A 30-year record of meteorological data acquired from the US EPA Exposure Assessment program (www.epa.gov/ceampubl) for the station at 
Table 3. Initial Land Type Soil Parameters and Persistent Land Type Soil Parameters for the Seven Land Types Delineated for the New Jersey Pine Barrens

\begin{tabular}{|c|c|c|c|c|c|c|c|c|c|c|c|c|}
\hline \multicolumn{2}{|c|}{ Land type name } & $\begin{array}{l}\text { SOMI C } \\
\text { surface }\end{array}$ & $\begin{array}{l}\text { SOMI N } \\
\text { surface }\end{array}$ & $\begin{array}{l}\text { SOMl C } \\
\text { soil }\end{array}$ & $\begin{array}{ll}\text { C } & \begin{array}{l}\text { SOM } \\
\text { soil }\end{array}\end{array}$ & \multicolumn{2}{|c|}{ SOM2 C } & SOM2 N & SOM3 C & SOM3 & $3 \mathrm{~N}$ & Mineral N \\
\hline \multicolumn{13}{|c|}{ Initial land type soil parameters $\left(\mathrm{g} \mathrm{m}^{-2}\right)$} \\
\hline Uplow & & 76.7 & 2.6 & 76.7 & 8.0 & \multicolumn{2}{|c|}{3212.0} & 53.5 & 277.4 & 15.4 & & 3.0 \\
\hline Upmed & & 78.3 & 2.8 & 94.8 & 10.0 & \multicolumn{2}{|c|}{3625.6} & 75.5 & 313.1 & 18.4 & & 3.0 \\
\hline Uphigh & & 76.0 & 2.7 & 87.4 & 9.1 & \multicolumn{2}{|c|}{3344.0} & 66.9 & 296.4 & 17.4 & & 3.0 \\
\hline Wetlow & & 138.8 & 4.6 & 122.8 & 12.8 & \multicolumn{2}{|c|}{4592.4} & 85.0 & 453.9 & 22.7 & & 3.0 \\
\hline Wetmed & & 130.7 & 4.4 & 148.5 & 15.6 & \multirow{2}{*}{\multicolumn{2}{|c|}{$\begin{array}{l}5108.4 \\
2367.2\end{array}$}} & 121.6 & 540.5 & 30.0 & & 3.0 \\
\hline Wethigh & & 61.9 & 1.9 & 61.87 & 6.4 & & & 44.7 & 209.8 & 10.5 & & 3.0 \\
\hline Plains & & 53.3 & 1.5 & 60.4 & 6.5 & \multicolumn{2}{|c|}{1988.0} & 47.3 & 1420.0 & 35.5 & & 3.0 \\
\hline $\begin{array}{l}\text { Land type } \\
\text { name }\end{array}$ & $\begin{array}{l}\text { Soil } \\
\text { depth } \\
\text { (cm) }\end{array}$ & $\begin{array}{l}\text { Fraction } \\
\text { clay }\end{array}$ & $\begin{array}{l}\text { Fraction } \\
\text { sand }\end{array}$ & $\begin{array}{l}\text { Field } \\
\text { capacity } \\
\text { fraction }\end{array}$ & $\begin{array}{l}\text { Wilting } \\
\text { point } \\
\text { fraction }\end{array}$ & $\begin{array}{l}\text { Storm } \\
\text { flow } \\
\text { fraction }\end{array}$ & $\begin{array}{l}\text { Base } \\
\text { flow } \\
\text { fraction }\end{array}$ & $\begin{array}{l}\text { Drain } \\
\text { fraction } \\
n\end{array}$ & $\begin{array}{l}\text { Atmosphe } \\
\text { deposition } \\
\text { slope }\end{array}$ & ric $\mathrm{N}$ & $\begin{array}{l}\text { Atmo } \\
\text { depo } \\
\text { inter }\end{array}$ & $\begin{array}{l}\text { ospheric N } \\
\text { osition } \\
\text { rcept }\end{array}$ \\
\hline \multicolumn{13}{|c|}{ Persistent land type soil parameters } \\
\hline Uplow & 100 & 0.045 & 0.894 & 0.104 & 0.035 & 0.4 & 0.4 & 0.75 & 0.02 & \multicolumn{3}{|c|}{0.05} \\
\hline Upmed & 100 & 0.102 & 0.76 & 0.143 & 0.066 & 0.4 & 0.4 & 0.75 & 0.02 & \multicolumn{3}{|c|}{0.05} \\
\hline Uphigh & 100 & 0.082 & 0.784 & 0.140 & 0.059 & 0.4 & 0.4 & 0.75 & 0.02 & \multicolumn{3}{|c|}{0.05} \\
\hline Wetlow & 100 & 0.048 & 0.889 & 0.118 & 0.043 & 0.2 & 0.2 & 0.5 & 0.02 & \multicolumn{3}{|c|}{0.05} \\
\hline Wetmed & 100 & 0.109 & 0.727 & 0.167 & 0.081 & 0.2 & 0.2 & 0.5 & 0.02 & \multicolumn{3}{|c|}{0.05} \\
\hline Wethigh & 100 & 0.042 & 0.895 & 0.380 & 0.159 & 0.2 & 0.2 & 0.5 & 0.02 & \multicolumn{3}{|c|}{0.05} \\
\hline Plains & 100 & 0.095 & 0.768 & 0.136 & 0.061 & 0.4 & 0.4 & 0.75 & 0.02 & \multicolumn{3}{|c|}{0.05} \\
\hline
\end{tabular}

Atlantic City, NJ was used to calculate fire weather inputs. Slope and azimuth maps, which aid in ROS calculations, were generated using standard GIS software from a $30 \mathrm{~m}$ resolution digital elevation model from the USGS National Elevation Dataset (http://ned.usgs.gov).

The Century succession extension and the Dynamic fire extension also interact through a table that describes the combustion fraction of dead wood and surface litter, dependent upon fire severity. We used combustion measurements of 1$\mathrm{h}$ (corresponding to surface litter in the Century extension) and 10-h (corresponding to fine wood) fuels to estimate the combustion fractions (Clark and others 2009a). These combustion measurements were made for 20 low and mid-severity fires and one severe fire (Clark and others 2009a, 2010a). Because the $1-h$ fuels corresponded directly to surface litter combustion, we needed only to extrapolate to more severe fires (Figure 4). However, we had only one measurement for total wood consumption from a high severity fire. Additionally, we had to extrapolate from fine wood to all wood consumption at low fire severities (Figure 4).

\section{Dynamic Biomass Fuels Extension}

We defined fuel types based on the classification defined by Scott and Burgan (2005). We used an iterative process to parameterize and calibrate the Dynamic Biomass Fuels extension (Syphard and others 2011) to best match the fuel conditions of the study area. The extension uses a tabular key to assign fuel types based on the tree species and age cohorts that occur at each site. We identified, for each FBFM in our study area, the primary tree species and the range of age cohorts for each species in the fuel type using our initial communities map and our reference plot data and used this information to construct an initial fuels key. We then ran the model for a single 5-year time step and compared the resultant fuels map with an existing FBFM map (John Hom, unpublished data) to identify areas of misclassification. This process was repeated until the modeled fuels best matched the FBFM fuels map. Due to the variety of fuel types and general uniformity of species composition and age structure in the study area, we added a set of parameters that allowed further separation of fuels based on land type. This allowed differentiation 
between, for example, upland and lowland sites with similar species composition but different fuels conditions.

\section{Management Scenarios}

We chose to simulate two management scenarios in addition to a baseline scenario representing contemporary fire management practices. Both scenarios represent potential future fire management regimes in the NJPB based on comments from fire managers and examination of state policy directives in New Jersey. The first management scenario represents an increase in fire management in areas with extensive WUI, especially those areas that are typically downwind from large, continuous forest stands with abundant hazardous fuels (for example, Clark and others 2009a). We identified fire regions with high fire occurrence and/or a large amount of WUI either within the region or adjacent to the region in the prevailing wind direction during fire season. We increased the number of ignitions in these fire regions by $50 \%$ to simulate an increase in prescribed fire fuels management in these areas. The second management scenario represents a longer response time to fires in all areas of the NJPB. The purpose of this scenario is to explore the effects of a more liberal burn

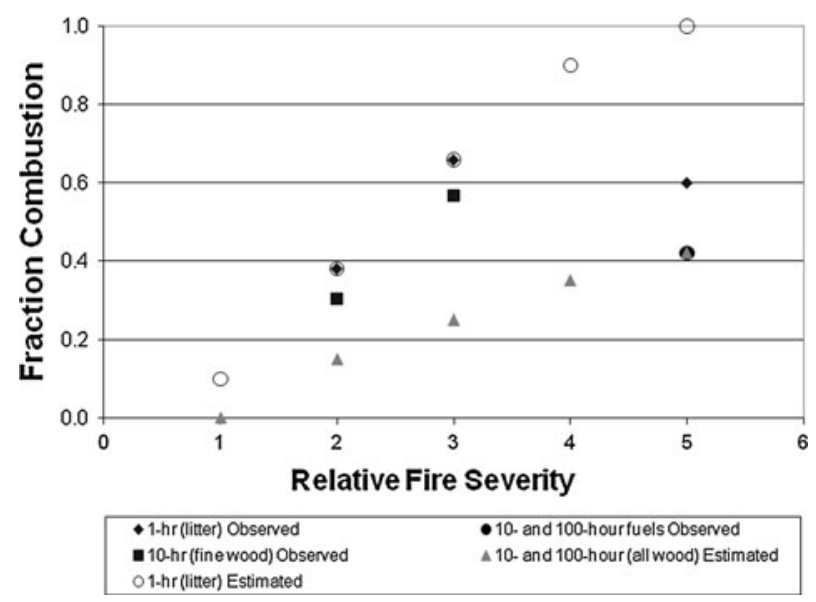

Figure 4. Mean observed fuel combustion for 1-h fuels (needle and leaf litter), 10-h fuels (fine wood), and all wood (10-h and 100-h fuels; $n=1$ ) across a gradient of relative fire severities in the New Jersey Pine Barrens. The standard deviation for 1 -h fuels was 0.19 and 0.05 (severities 2 and 3, $n=14$ and 6, respectively) and for 10h fuels was 0.25 and 0.14 (severities 2 and $3, n=14$ and $6)$. Only a single sample was available for a high severity (5) fire. Estimated fuel consumption fractions (gray or open symbols) represent the combustion values input into the Century succession extension for relative fire severities. policy-regardless of the ultimate cause-which would allow fires to burn longer to reduce fuels across the landscape. For this scenario we increased the average fire duration by $50 \%$ in all fire regions. Each scenario was replicated five times to evaluate variation due to stochastic fire events and climate. The number of replicates was a necessary compromise between expected stochastic variation and requisite computational time.

\section{RESUlts}

\section{Carbon Cycling Calibration and Validation}

Our calibration and validation of flux tower NEE data was generally successful (Figure 5). At the oak-pine stand at the Silas Little Experimental Forest, the model generally captures the timing and magnitude of NEE for 2005 and 2006. However, the agreement is poor during the growing season in 2007, when the site experienced heavy defoliation due to a Gypsy moth outbreak. Likewise, predicted and measured NEE for the pine-oak stand at Fort Dix were generally similar for 2005 although divergent for 2006 and 2007, again due to Gypsy moth defoliation. At Cedar Bridge, NEE was slightly delayed in the model results for spring of 2005. The first 4 months of 2005 were colder than average and modeled heterotrophic respiration was very low, leading to a larger predicted efflux of carbon in May, June, and July when temperatures warmed. Combining data from all sites for years without disturbance, the model appears to modestly overestimate NEE during summer, although the overall agreement is satisfactory (Figure 6; adjusted $\left.r^{2}=0.89 ; p<0.001 ; n=41\right)$.

Although calibration required adjustments to $\mathrm{N}$ deposition, the end result was within reasonable bounds for expected wet and dry deposition. Simulated $\mathrm{N}$ deposition calibration was $2.1 \mathrm{~g} \mathrm{~N} \mathrm{~m}^{-2} \mathrm{y}^{-1}$ averaged across all simulations. This compares with the $2.4 \mathrm{~g} \mathrm{~N} \mathrm{~m}^{-2} \mathrm{y}^{-1}$ estimated by Gao and others (2007) for the coasts of NJ near Atlantic City.

\section{Dynamic Biomass Fuels Calibration}

We compared the final iteration of the dynamic biomass fuels calibration to the FBFM map (Figure 7). Differences between maps are due to the different inputs used to generate each map and the errors associated with each map. In addition, most species in the Pine Barrens occur in multiple fuel types, which amplified discrepancies within the mixed forest types. The largest differences between 

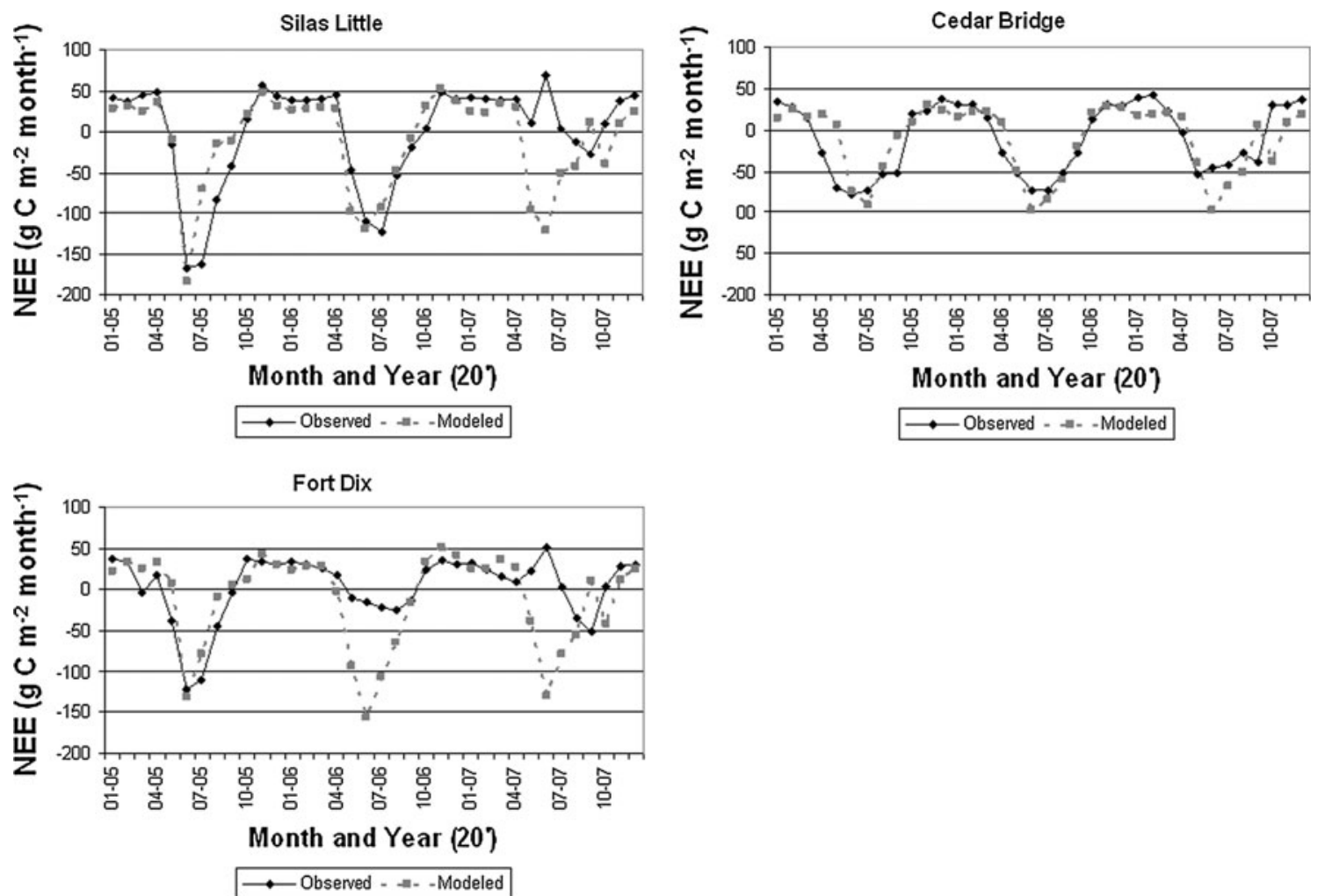

Figure 5. Comparison of LANDIS-II Century Succession extension monthly net ecosystem exchange $\left(\mathrm{NEE}, \mathrm{g} \mathrm{C} \mathrm{m}^{-2}\right.$ month $^{-1}$ ) and measured NEE at the three eddy flux tower sites in the New Jersey Pine Barrens.

the model output and the FBFM fuels map occurred in the mixed and conifer wetland areas. Fortunately, the mixed and conifer fuel types do not have fast spread rates or large fuel beds, presumably reducing the effects of the differences between the two classifications. Another area of discrepancy is the location and extent of pine plains fuel types (SH9, Figure 7).

\section{Dynamic Fire System Calibration}

Comparing the FBFM fuel types and fuel types we developed for the Dynamic Fire extension, the ROS for the eight fuel types were similar for the fine fuel moisture contents that occur during the fire season, with an $r^{2}$ ranging from 0.67 to 0.93 , and root mean square error (RMSE) values ranging from 0.38 to $5.13 \mathrm{~m} \mathrm{~min}^{-1}$, or 17 to $28 \%$ of the average FBFM ROS (Table 4). When weighted by the percent of total study area represented by each fuel type, the RMSE was $2.7 \mathrm{~m} \mathrm{~min}^{-1}$ and the percent of average ROS was $22 \%$. A portion of the error is caused by the "cap" on ROS in the FBFM model that is not present in the Dynamic Fire extension ROS algorithms.
Calibration of the fire size and ignitions required trade-offs between accuracy in the number of ignitions and the size of fires (Table 5). Across most

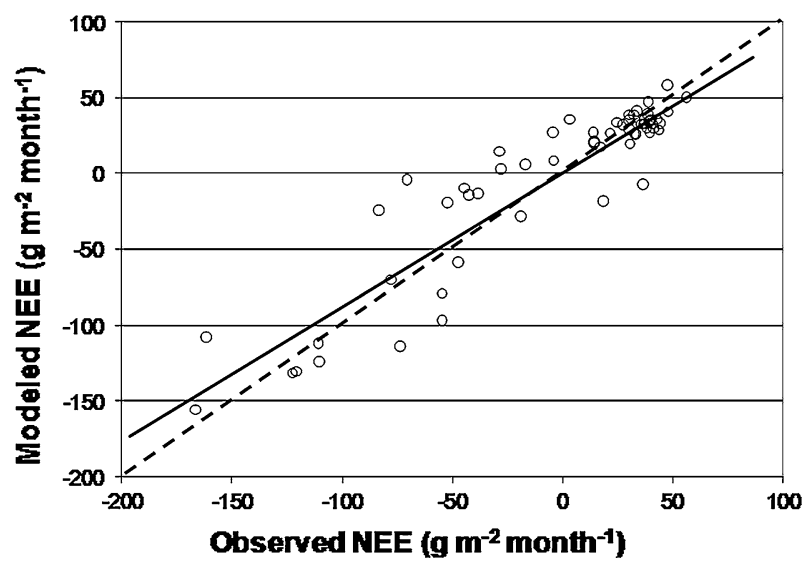

Figure 6. Comparison of modeled NEE $\left(\mathrm{g} \mathrm{C} \mathrm{m}^{-}\right.$ ${ }^{2}$ month $^{-1}$ ) and observed NEE from three upland eddy flux tower sites in the New Jersey Pine Barrens excluding years with heavy Gypsy moth defoliation. The solid line represents a linear regression of modeled against observed (adjusted $r^{2}=0.89 ; P<0.001 ; n=41$ ). The dashed line represents a 1:1 relationship. 


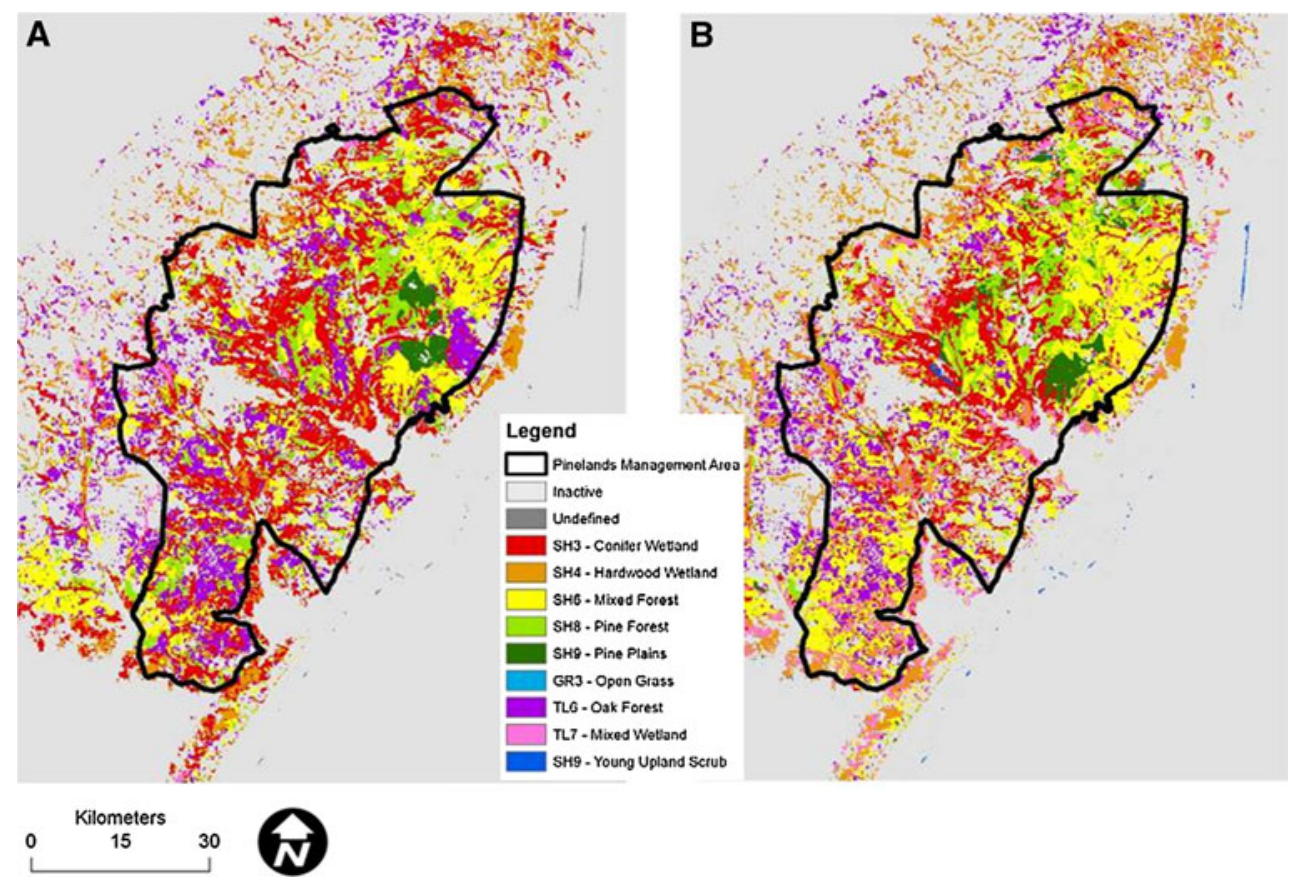

Figure 7. Comparison of eight simulated fuel types from the LANDIS-II model with the Dynamic Biomass Fuel extension (A) and fuel types mapped using classified satellite data $(\mathbf{B})$ in the New Jersey Pine Barrens study area.

fire regions, modeled baseline fire sizes were within one standard deviation (calculated from five model replicates) of empirical estimates. Similarly, the modeled number of fire ignitions were typically less than one standard deviation $(n=5$ replicates) from empirical estimates. The empirical estimates themselves contain a degree of uncertainty due to the challenges of measuring fire perimeters and actual number of ignitions.

Although a lack of long-term field data makes comparison difficult, our simulated patterns of fuel dynamics were consistent with historical observations. Many more low severity fires and only a few high severity fires occurred. Fire severity also follows the expected behavior, with the magnitude of fire severity generally tracking fuel type (Figure 8). After a series of moderate severity fires, upland oak and mixed pine-oak forests tend to shift towards a pine-dominated fuel type. Repeated high severity upland fires will tend to result in pinedominated or scrub dominated fuel types, consistent with the pine plains forest stands. Only the most severe simulated fire resulted in the complete loss of tree cover in stands and typically this complete loss of cover is only present in portions of the most severe fire areas (Figure 8). Over time such areas will be expected to revert to pitch pine and our simulations reflected this dynamic. Moderate

Table 4. Scott and Burgan (2005) Fuel Types and the Parameters for the Corresponding Dynamic Fire System Extension Parameters

\begin{tabular}{llllllllr}
\hline $\begin{array}{l}\text { Scott and Burgan } \\
\text { fuel type }\end{array}$ & $a$ & $b$ & $c$ & $q$ & Slope & Intercept & $R^{2}$ & RMSE \\
\hline SH3 & 89.38 & 0.00110 & 0.797 & 0.9 & 0.95 & -0.330 & 0.800 & 0.559 \\
SH4 & 88.63 & 0.00036 & 0.525 & 0.9 & 0.95 & -0.591 & 0.595 \\
SH6 & 89.50 & 0.01797 & 0.993 & 0.9 & 0.95 & -2.034 & 0.859 & 3.095 \\
SH8 & 37.23 & 0.10646 & 2.105 & 0.9 & 0.95 & -2.010 & 0.933 & 2.279 \\
SH9 & 89.89 & 0.06671 & 1.554 & 0.9 & 0.95 & -3.967 & 0.912 & 5.131 \\
GR3 & 88.96 & 0.00569 & 0.614 & 0.9 & 0.95 & -1.949 & 0.669 \\
TL6 & 13.84 & 0.12376 & 2.827 & 0.9 & 1.0 & -0.439 & 0.916 & 1.107 \\
TL7 & 89.25 & 0.00044 & 0.715 & 0.9 & 0.95 & -0.244 & 0.792 & 0.382
\end{tabular}

The Scott and Burgan (2005) fuel type rate of spread (ROS) was compared to the Dynamic Fire extension ROS from a range of wind speeds and fuel moistures and $R^{2}$ and RMSE were calculated by comparing their respective ROS. 
severity fires within pitch pine stands resulted in little or no change in fuel type, accurately reflecting fuel dynamics observations.

Over long periods without disturbance, fuel types appropriately tracked changes in vegetation composition and structure. For example, undisturbed pine stands tended to become mixed pine-oak stands over the length of the simulation. Likewise, upland mixed stands shifted towards oak-dominated stands in the absence of disturbance.

\section{Current Management Scenario}

Simulated ANPP and NEE demonstrated a high degree of temporal variability, reflecting their sensitivity to annual variation in climate. Neither upland nor wetland forests have a consistently higher ANPP although the plains are much lower and experience a modest reduction through time (Figure 9A). Similarly, simulated annual NEE was highly variable over time (Figure 9B). The only clear distinction is that the plains generally have a higher NEE (less carbon uptake) and more variable NEE as expected due to slower growth and greater susceptibility to fire. The simulations indicate a modest increase in NEE over time. This is due to the aging of the forests-which are currently similarly aged due to logging at the beginning of the 20th century-and a concomitant increase in detritus and heterotrophic respiration.

Results of the baseline management scenario suggest that overall the upland and wetland forests of the NJPB will continue to accumulate carbon over the next 100 years under current conditions (Figure 10). Accumulation will occur within all the major carbon pools: live biomass, soil organic carbon (SOC), and surface detrital pools. Live carbon was similar for the upland and wetland forests, although the wetlands with the highest soil water holding capacity exceed all others after 20 years (Figure 10A). Live biomass begins to taper and decline near the end of our simulations, again reflecting senescence of trees that regenerated about a century ago. SOC accrual is a function of detrital inputs and respiration, and change is much less subject to climatic or disturbance variation over time than detrital or live carbon and the relatively constant accrual therein reflects this dynamic (Figure 10C). In contrast, the pine plains have relatively low and constant carbon pools due to their slow growth rate, frequent fire regime, and low maximum stem and branch biomass. Estimates of carbon storage in the pine plains became increasingly uncertain over time due to their relatively small area and susceptibility to large wildfires. 


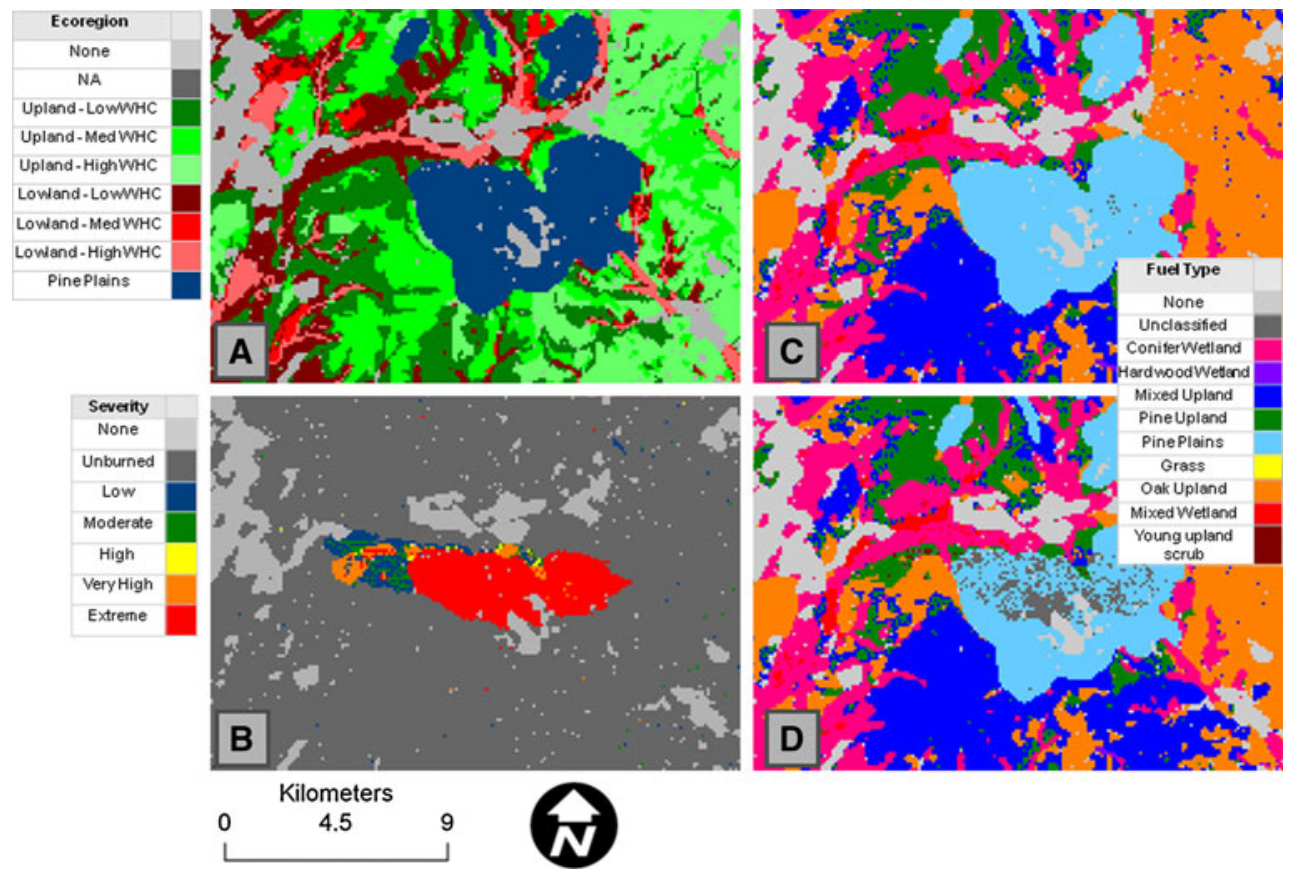

Figure 8. Example of the interactions between fuel types and fire severity. The area at the center of each image is the pine plains west of Warren Grove, NJ. This fire ignited to the west of the pine plains and burned at low to moderate severity (A; blues and greens) but increased to high severity $(\mathbf{B}$; red) when it entered the more xeric pine plains. The figures $\mathbf{C}$ and $\mathbf{D}$ on the right show the effects of the same fire on fuels in the area. The low severity portion of the fire resulted in subtle changes in fuel type, if any changes at all. In the high severity area, the fuel type remains the same (pine plains) 5 years after the fire, with some areas showing grass fuels due to extremely severe fire killing all cohorts.

\section{Comparison Among Scenarios}

The accumulation of carbon in these systems is the product of continued re-growth of these relatively young forests and reflects the recovery following the intense disturbance regime (harvest and fire) of the 19th and early 20th centuries. On an areal basis, only the pine plains are projected to have significantly less projected carbon under the two management regimes explored than under the control scenario (Figure 11A). Our simulations indicate that although wetland and upland forests begin with a similar carbon density, the wetland forests would eventually exceed upland forests.

On a total carbon basis (Figure 11B, D), expressed as $\mathrm{Tg} \mathrm{C}$, differences due to management activities are negligible except in the pine plains. However, the wetland forests contain less total carbon than upland forests as they are a substantially smaller portion of the landscape. Management remains significant in the plains, although total carbon in the plains represents less than $2 \%$ of the total landscape carbon.

\section{Discussion}

Our comparison of modeled to empirical flux tower data indicated that the model generally captures the timing and magnitude of NEE in the absence of Gypsy moth defoliation. Model predictions diverge from empirical measurements substantially during periods of defoliation which resulted in substantial reductions in leaf area. Defoliation occurred at the Silas Little and Cedar Bridge towers in 2007 and at the Fort Dix tower in 2006 and 2007 during the peak time of the summer for $\mathrm{CO}_{2}$ uptake (June 1July 15th, Clark and others 2010 b). In contrast to defoliation by Gypsy moth or pitch pine looper (Lambdina pellucidaria Grote and Robinson), many of the fires in the Pine Barrens occur during the late winter and spring, and thus have less of an impact on peak leaf area during the early summer. In this research, we did not attempt to simulate the shortor long-term effects of insect defoliation.

Our results suggest that changes to forest management practices of the magnitude simulated in our study in the NJPB will have little effect on forest carbon budgets in the immediate future, assuming that climate does not change appreciably. 

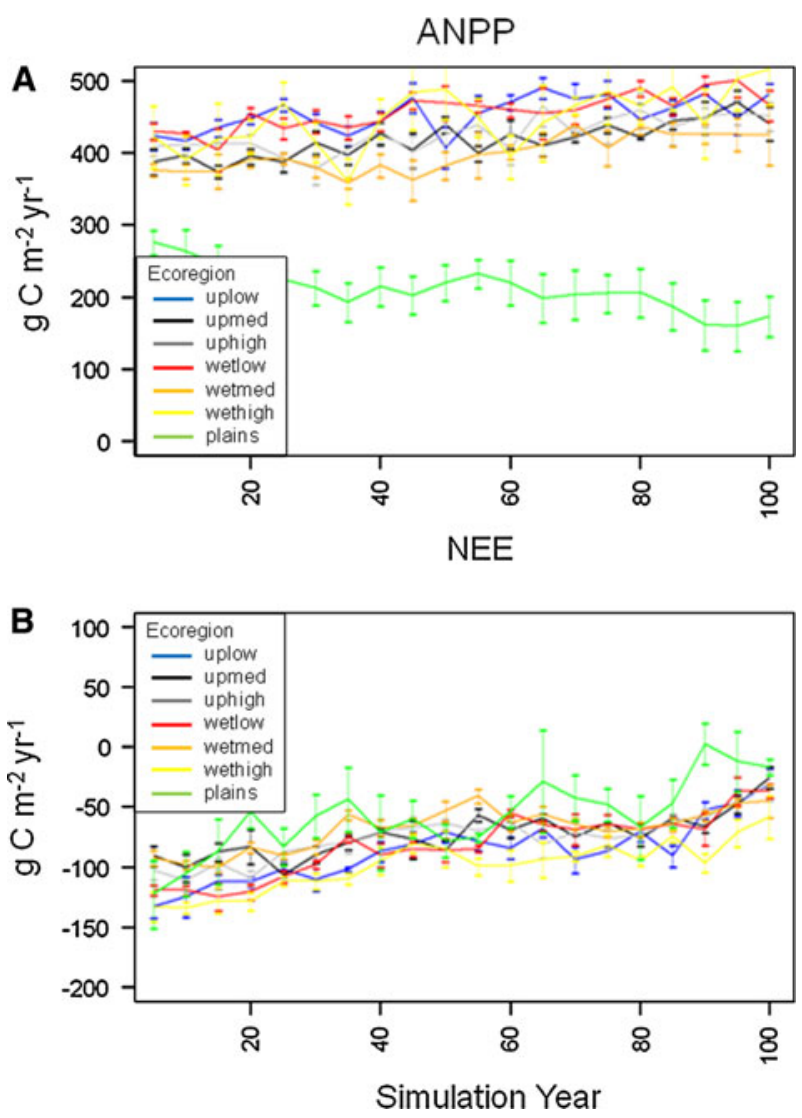

Figure 9. Ecosystem process rates for seven land types assuming current management continues in the NJ Pine Barrens: A aboveground net primary productivity (ANPP), B net ecosystem exchange (NEE). Units are $\mathrm{g} \mathrm{C} \mathrm{m}^{-2} \mathrm{y}^{-1}$. Each year represented is the average of 5 replicates.

Although there was a significant change in total carbon storage in the pine plains, they represent a small area $(<5 \%$ of the total landscape $)$. These results build upon our prior research (Scheller and others 2008), which indicated that forest and fire management may have a small but directional effect on tree species composition.

In so much as our increased prescribed burning ('plus ignitions') scenario represents a modest effort to reduce fire severity, there does not appear to be a large cost in terms of reduced carbon sequestration. The resiliency of upland forests in the NJPB is partially due to epicormic budding of pitch and shortleaf pine, and prolific sprouting of oaks and understory shrubs that occurs following fire, resulting in the rapid recovery of leaf area index (LAI). Because productivity is tightly linked to LAI in these stands (for example, Clark and others 2010b), relatively low intensity fires have little effect on long-term productivity. Similarly, Chiang and others (2008) found no long-term impacts due to thinning or prescribed burning on aboveground carbon in oak forests in Ohio. In contrast, fuel treatments could substantially reduce aboveground carbon in Oregon (Mitchell and others 2009).

Our simulations suggest that regardless of any minor modifications to existing management practices, the NJPB will continue to accrue carbon over the next 100 years. We hypothesize that this carbon accrual is a result of repeated logging and fires over the past 200 years (Wacker 1979) that depleted carbon stocks that are likely to still be recovering in many regions across North America (for example, Houghton 1999; Houghton and Hackler 2000; Goodale and others 2002; Rhemtulla and others 2009). Our simulated carbon sequestration trajectory is consistent with results from the ecosystem demography model for the eastern United States (Albani and others 2006) and from the LANDIS-II model applied to Massachusetts (Thompson and others in press).

The relative stability of total carbon on the plains (Figure 11B) and the slow accumulation in wetland and upland regions (Figure 11D) despite recurring fires reflects the adaptation of the native vegetation to fire (Givnish 1981). Productivity quickly rebounds following fire and the landscape remains forested even after the most severe fires. In addition, forest fragmentation and active fire suppression limits fire spread and fire size (Scheller and others 2008), not allowing any single fire to release a large amount of carbon under most circumstances (Clark and others 2009b). Nevertheless, our simulations with replicates demonstrate the large potential variation due to stochastic wildfire events (Figure 11D). Previous modeling studies in fireprone systems in northern Minnesota have indicated that such variation is caused almost entirely by wildfires with little variation attributable to succession (Scheller and others 2005; Ravenscroft and others 2010).

How long carbon accrual would continue beyond the next 100 years was not explored, however, our NEE (Figure 9B) and live carbon (Figure 10A) estimates suggest that the rate of carbon accrual may begin to slow after 100 years, more so in the upland forests. How long wetland forests will continue to sequester carbon is highly uncertain as there are no flux towers representing wetland forests and there are few reference stands for estimating maximum potential aboveground live biomass and the capacity for wetter soils to continue sequestering carbon. Nevertheless, it appears that a carbon emissions mitigation strategy should protect these forests and their embodied carbon first as they have an overall greater potential for 

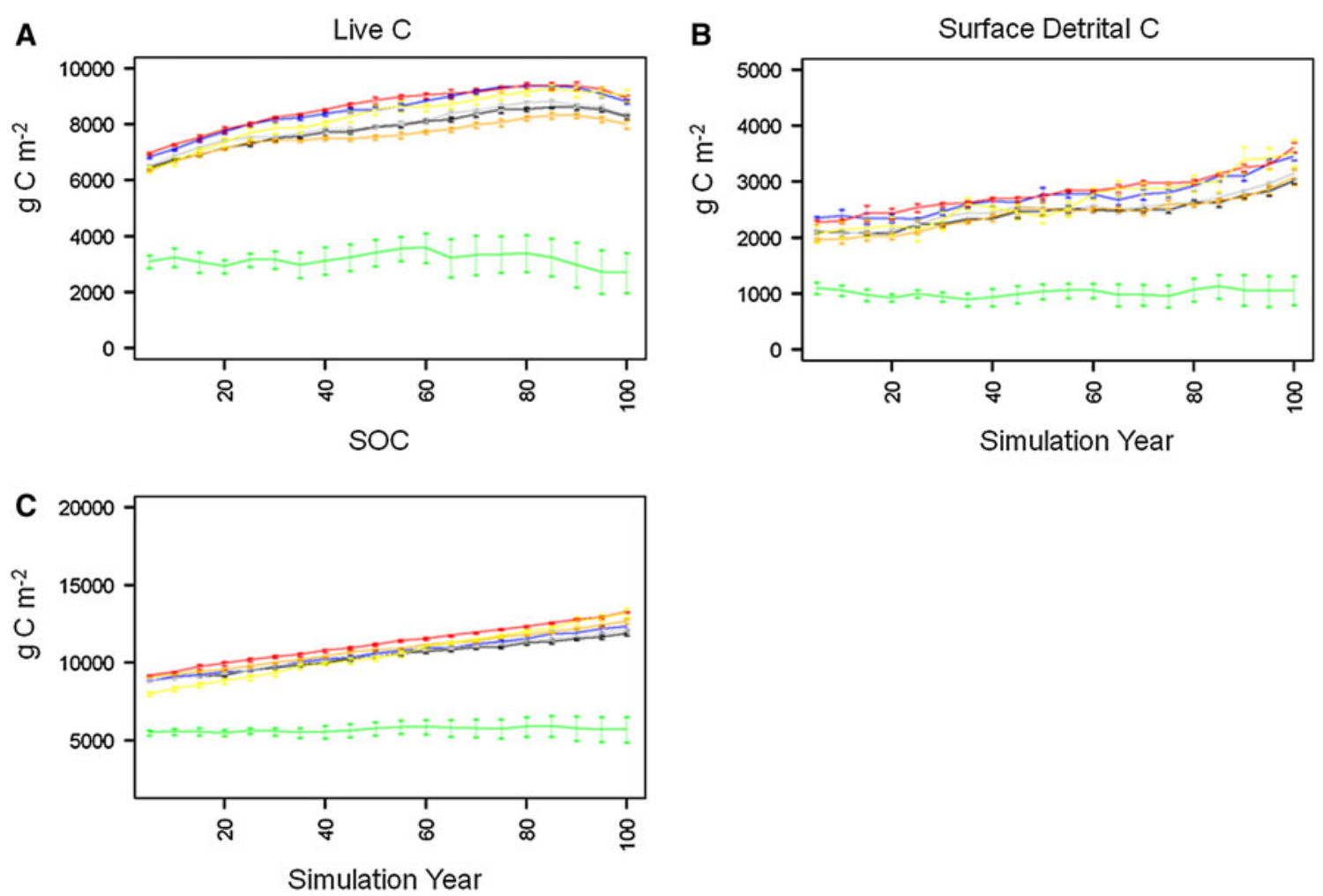

Figure 10. Carbon pools $\left(\mathrm{g} \mathrm{C} \mathrm{m}^{-2}\right)$ for seven land types assuming current management continues in the NJ Pine Barrens: A live carbon, including leaves/needles, wood, roots; B detrital carbon, including fine and coarse litter, and dead roots; C soil organic carbon, including all remaining carbon pools.

carbon storage due to the long lifespan and potential for Atlantic white cedar to reach large biomass values.

Our simulations, although calibrated and validated to the extent possible, are not a complete exploration of all current processes or future changes. Research is currently being conducted that will incorporate the effects of climate change and Gypsy moth defoliation, a significant defoliator of oak and oak-mixed forests (Johnson and others 2006). Climate change could serve as a significant trigger that alters the successional dynamics, the fire regime, and the rate of Gypsy moth defoliation (Logan and others 2007; Kurz and other 2008). Although apparently a conservative system, we cannot rule out the potential for large changes in total ecosystem carbon under insect defoliation or climate change and the interactive effects of defoliation, climate change, and fire are only poorly known at this time. Finally, our simulations are limited by the available data for parameterizing the model. This is particularly notable in our initial soil organic carbon estimates, which are based on limited samples extrapolated across broad scales and subsequently averaged by land type.

Part of the difficulty in accounting for carbon emissions from forest management is the challenge of properly tracking all natural carbon components (for example, photosynthesis, respiration). We expand on recent studies that examine the longerterm implications of management on carbon (Chiang and others 2008; Hurteau and North 2009) by explicitly considering treatment and fire effects on soil carbon. Recent studies have highlighted additional components of the carbon cycle that are frequently overlooked including understory vegetation dynamics (Campbell and others 2007) and the offsetting of carbon emissions during fuel treatments (Finkral and Evans 2008).

\section{Conclusions}

Our results indicate that carbon in the NJPB is likely still recovering from extensive disturbances prior to the current era of fire suppression and minimal logging. Carbon will continue to steadily accrue over the next 100 years despite an active 

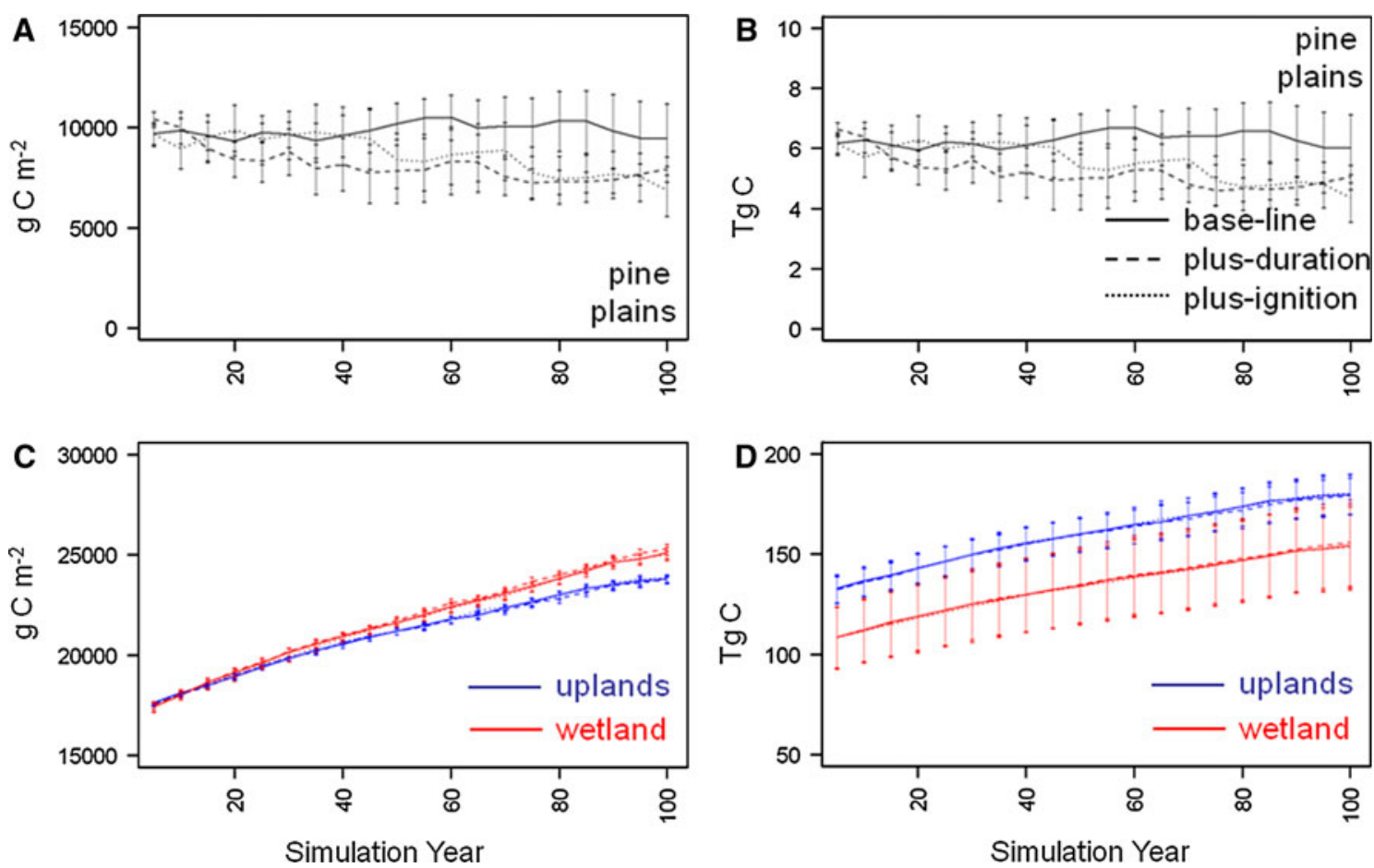

Figure 11. Total carbon including all live pools, dead pools, and soil organic carbon for three management scenarios (baseline, plus duration, and plus ignition) and for three forest types (wetland, uplands, and pine plains): $\mathbf{A}, \mathbf{C}$ on an areal basis; B, D Tg C for the forested areas within our study area, the Pinelands Management Area.

fire regime and fire management activities. The system is generally resilient to these more limited perturbations, partly due to the functional traits of the dominant vegetation. Ongoing research that will consider projected climate changes and insect defoliation will further elucidate disturbance effects on ecosystem carbon and overall ecosystem resilience.

\section{ACKNOWLEDGMENTS}

The US Forest Service Forest Health Monitoring program (NE-F-08-01), National Fire Plan, and the Eastern Landfire Protoype has generously funded aspects of this research. Melissa Lucash and Jonathan Thompson provided a critical review of the manuscript.

\section{REFERENCES}

Albani M, Medvigy D, Hurtt GC, Moorcroft PR. 2006. The contributions of land-use change, $\mathrm{CO}_{2}$ fertilization, and climate variability to the Eastern US carbon sink. Glob Change Biol $12: 2370-90$

Amiro BD, Barr AG, Barr JG, Black TA, Bracho R, Brown M, Chen J, Clark KL, Davis KJ, Desai AR, Dore S, Engel V, Fuentes JD, Goulden ML, Kolb TE, Lavigne MB, Law BE, Margolis HA, Martin T, McCaughey JH, Montes-Helu M, Noormets A, Randerson JT, Starr G, Xiao J. 2010. Ecosystem carbon dioxide fluxes after disturbance in forests of North America. J Geophys Res Biogeosci 115:G00K02.
Boerner RE. 1981. Forest structure dynamics following wildfire and prescribed burning in the New Jersey pine barrens. Am Midl Nat 105:321-33.

Campbell J, Donato D, Azuma D, Law B. 2007. Pyrogenic carbon emission from a large wildfire in Oregon, United States. J Geophys Res 112:G04014.

Chiang J-M, McEwan RW, Yaussy DA, Brown KJ. 2008. The effects of prescribed fire and silvicultural thinning on the aboveground carbon stocks and net primary production of overstory trees in an oak-hickory ecosytem in Ohio. For Ecol Manage 255:1584-94.

Clark KL, Skowronski N, Hom J, Duveneck M, Pan Y, Van Tuyl S, Cole J, Patterson M, Maurer S. 2009a. Decision support tools to improve the effectiveness of hazardous fuel reduction treatments. Int J Wildland Fire 18:268-77.

Clark KL, Skowronski N, Hom J, Heilman WE. 2009b. Fireflux Experiments in the New Jersey Pine Barrens. Kalispell (MT): Eighth Symposium on Fire and Forest Meteorology. 7 pp.

Clark KL, Skowronski N, Gallagher M, Heilman W, Hom J. 2010a. Fuel consumption and particulate emissions during fires in the New Jersey Pinelands. Birmingham (AL): 3rd Fire Behavior and Fuels Conference.

Clark KL, Skowronski N, Hom J. 2010b. Invasive insects impact forest carbon dynamics. Glob Change Biol 16:88-101.

Cogbill CV, Burk J, Motzkin G. 2002. The forests of presettlement New England, USA: spatial and compositional patterns based on town proprietor surveys. J Biogeogr 29:1279-304.

Finkral AJ, Evans AM. 2008. The effects of a thinning treatment on carbon stocks in a northern Arizona ponderosa pine forest. For Ecol Manage 255:2743-50.

Forman RTT, Boerner RE. 1981. Fire frequency and the Pine Barrens of New Jersey. Bull Torrey Bot Club 108:34-50. 
Gao Y, Kennish MJ, Flynn AM. 2007. Atmospheric nitrogen deposition to the New Jersey coastal waters and its implications. Ecol Appl 17:S31-41.

Givnish TJ. 1981. Serotiny, geography, and fire in the Pine Barrens of New Jersey. Evolution 35:101-23.

Goodale CL, Apps MJ, Birdsey RA, Field CB, Heath LS, Houghton RA, Jenkins JC, Kohlmaier GH, Kurz W, Liu SR, Nabuurs GJ, Nilsson S, Shvidenko AZ. 2002. Forest carbon sinks in the northern hemisphere. Ecol Appl 12:891-9.

Goward SN, Masek JG, Cohen W, Moisen G, Collatz GJ, Healey S, Houghton RA, Huang C, Kennedy R, Law B, Powell S, Turner D, Wulder MA. 2008. Forest disturbance and North American carbon flux. Eos 89:105-6.

Hansen MH, Frieswyk T, Glover JF, Kelly JF. 1992. The eastwide forest inventory data base: users manual. St. Paul (MN): GTR NC-151.

Houghton RA. 1999. The annual net flux of carbon to the atmosphere from changes in land use 1850-1990. Tellus B 51:298-313.

Houghton RA, Hackler JL. 2000. Changes in terrestrial carbon storage in the United States. I: the roles of agriculture and forestry. Glob Ecol Biogeogr 9:125-44.

Hurteau M, North M. 2009. Fuel treatment effects on tree-based forest carbon storage and emissions under modeled wildfire scenarios. Front Ecol Environ 7:409-14.

Johnson DM, Liebhold AM, Bjornstad ON. 2006. Geographical variation in the periodicity of gypsy moth outbreaks. Ecography 29:367-74.

Kurczewski FE, Boyle HF. 2000. Historical changes in the Pine Barrens of central Suffolk County, New York. Northeast Nat 7:95-112.

Kurz WA, Dymond CC, Stinson G, Rampley GJ, Neilson ET, Carroll AL, Ebata T, Safranyik L Jr. 2008. Mountain pine beetle and forest carbon feedback to climate change. Nature 452:987-90.

Lathrop Jr. RG, Kaplan MB. 2004. New Jersey Land Use/Land Cover Update: 2000/2001. New Jersey: Department of Environmental Protection.

Lindroth A, Lagergren F, Grelle A, Klemedtsson L, Langvall O, Weslien P, Tuulik J. 2009. Storms can cause Europe-wide reduction in forest carbon sink. Glob Change Biol 15:346-55.

Logan JA, Régnière J, Gray DR, Munson AS. 2007. Risk assessment in the face of a changing environment: gypsy moth and climate change in Utah. Ecol Appl 17:101-17.

McCormick J, Jones L. 1973. The Pine Barrens: vegetation and geography. New Jersey State Museum. Research Report Number 3.

Mitchell SR, Harmon ME, O'Connell KEB. 2009. Forest fuel reduction alters fire severity and long-term carbon storage in three Pacific Northwest ecosystems. Ecol Appl 19:643-55.

NRCS. 2011 . National SSURGO database [Online]. USDA-NRCS. Available at http://soils.usda.gov/survey/geography/ssurgo/ (verified 5 July 2011).

Pan Y, Birdsey R, Hom J, McCullough K, Clark K. 2006. Improved estimates of net primary productivity from MODIS satellite data at regional and local scales. Ecol Appl 16:125-32.

Parton WJ, Anderson DW, Cole CV, Steward JWB. 1983. Simulation of soil organic matter formation and mineralization in semiarid agroecosystems. In: Lowrance RR, Todd RL, Asmussen LE, Leonard RA, Eds. Nutrient cycling in agricultural ecosystems. Athens (GA): The University of Georgia, College of Agriculture Experiment Stations.
Parton WJ, Scurlock JMO, Ojima DS, Gilmanov TG, Scholes RJ, Schimel DS, Kirchner T, Menaut JC, Seastedt T, Garcia Moya E, Kamnalrut A, Kinyamario JI. 1993. Observations and modeling of biomass and soil organic matter dynamics for the grassland biome worldwide. Glob Biogeochem Cycles 7:785-809.

Ravenscroft CR, Scheller RM, Mladenoff DJ, White MS. 2010. Simulating forest restoration in a mixed ownership landscape under climate change. Ecol Appl 20:327-46.

Rhemtulla JM, Mladenoff DJ, Clayton MK. 2009. Historical forest baselines reveal potential for continued carbon sequestration. Proc Natl Acad Sci 106:6082-7.

Rhodehamel EC. 1979. Geology of the Pine Barrens of New Jersey. In: Forman RTT, Ed. Pine Barrens: ecosystem and landscape. New York (NY): Academic Press. p 39-58.

Scheller RM, Mladenoff DJ, Crow TR, Sickley TA. 2005. Simulating the effects of fire reintroduction versus continued fire absence on forest composition and landscape structure in the Boundary Waters Canoe Area, Northern Minnesota, USA. Ecosystems 8:396-411.

Scheller RM, Domingo JB, Sturtevant BR, Williams JS, Rudy A, Gustafson EJ, Mladenoff DJ. 2007. Design, development, and application of LANDIS-II, a spatial landscape simulation model with flexible spatial and temporal resolution. Ecol Model 201:409-19.

Scheller RM, Van Tuyl S, Clark K, Hayden NG, Hom J, Mladenoff DJ. 2008. Simulation of forest change in the New Jersey Pine Barrens under current and pre-colonial conditions. For Ecol Manage 255:1489-500.

Scheller RM, Sturtevant BR, Gustafson EJ, Mladenoff DJ, Ward BC. 2010. Increasing the reliability of ecological models using modern software engineering techniques. Front Ecol Environ 8:253-60.

Scheller RM, Hua D, Bolstad PV, Birdsey RA, Mladenoff DJ. 2011. The effects of forest harvest intensity in combination with wind disturbance on carbon dynamics in Lake States mesic forests. Ecol Model 222:144-53.

Schimel DS, Braswell BH, Holland EA, McKeown R, Ojima DS, Painter TH, Parton WJ, Townsend AR. 1994. Climatic, edaphic, and biotic controls over storage and turnover of carbon in soils. Glob Biogeochem Cycles 8:279-93.

Scott JH, Burgan RE. 2005. Standard fire behavior fuel models: a comprehensive set for use with Rothermel's surface fire spread model. Fort Collins (CO): U.S. Department of Agriculture FS, Rocky Mountain Research Station. Gen. Tech. Rep. RMRS-GTR-153.

Service UF. 2007. The Forest Inventory and Analysis Database: Database Description and Users Guide Version 3.0. Forest Inventory and Analysis Program, U.S.D.A. FS.

Skowronski N, Clark K, Nelson R, Hom J, Patterson M. 2007. Remotely sensed measurements of forest structure and fuel loads in the Pinelands of New Jersey. Remote Sens Environ 108:123-9.

Sturtevant BR, Scheller RM, Miranda BR, Shinneman D. 2009. Simulating dynamic and mixed-severity fire regimes: a process-based fire extension for LANDIS-II. Ecol Model 220: 3380-93.

Syphard AD, Scheller RM, Ward BC, Spencer WD, Strittholt JR. 2011. Simulating landscape-scale effects of fuels treatments in the Sierra Nevada, California. Int J Fire Manage 20:364-83.

Tedrow JCF. 1986. Soils of New Jersey. Malabar (FL): Station NJAE. New Jersey Agricultural Experiment Station Publication A-15134-1-82. 
Thompson JR, Foster DR, Scheller RM, Kittredge D. in press. The influence of climate change, timber harvest, and rural development on forest biomass and composition in Massachusetts, USA. Ecological Applications.

Thornton PE, Law BE, Gholz HL, Clark KL, Falge E, Ellsworth DS, Goldstein AH, Monson RK, Hollinger D, Falk M, Sparks JP. 2002. Modeling and measure the effects of disturbance history and climate on carbon and water budgets in evergreen needleleaf forests. Agric For Meteorol 115:185-222.

Throop HL, Holland EA, Parton WJ, Ojima DS, Keough CA. 2004. Effects of nitrogen deposition and insect herbivory on patterns of ecosystem-level carbon and nitrogen dynamics: results from the Century model. Glob Change Biol 10:1092-105.
Van Wagner CE. 1987. Development and structure of the Canadian Forest Fire Weather Index System. Ottawa (ON): Forestry Technical Report 35.

Wacker PO. 1979. Human exploitation of the New Jersey Pine Barrens before 1900. In: Forman RTT, Ed. Pine Barrens: ecosystem and landscape. New Brunswick (NJ): Rutgers University Press.

Wright CS, Ottmar RD, Vihnanek RE. 2007. Stereo photo series for quantifying natural fuels. Volume VIII: hardwood, pitch pine, and red spruce/basam fire types in the Northeastern United States. Boise (ID): National Wildfire Coordinating Group NIFC. PMS 840. 